\title{
Association of polymorphisms in solute carrier family 27 , isoform A6 (SLC27A6) and fatty acid-binding protein-3 and fatty acid-binding protein-4 (FABP3 and FABP4) with fatty acid composition of bovine milk
}

\author{
R. A. Nafikov, ${ }^{*}$ J. P. Schoonmaker, ${ }^{, 1}$ K. T. Korn, ${ }^{\star}$ K. Noack, ${ }^{*}$ D. J. Garrick, ${ }^{*}$ K. J. Koehler, $†$ \\ J. Minick-Bormann, $\ddagger$ J. M. Reecy, ${ }^{*}$ D. E. Spurlock, ${ }^{*}$ and D. C. Beitz ${ }^{* 2}$ \\ *Department of Animal Science, and \\ †Department of Statistics, lowa State University, Ames 50011 \\ ‡Department of Animal Sciences and Industry, Kansas State University, Manhattan 66506
}

\begin{abstract}
The main goal of this study was to develop tools for genetic selection of animals producing milk with a lower concentration of saturated fatty acids (SFA) and a higher concentration of unsaturated fatty acids (UFA). The reasons for changing milk fatty acid (FA) composition were to improve milk technological properties, such as for production of more spreadable butter, and milk nutritional value with respect to the potentially adverse effects of SFA on human health. We hypothesized that genetic polymorphisms in solute carrier family 27, isoform A6 (SLC27A6) fatty acid transport protein gene and fatty acid binding protein (FABP)-3 and FABP-4 (FABP3 and FABP4) would affect the selectivity of FA uptake into, and FA redistribution inside, mammary epithelial cells, resulting in altered FA composition of bovine milk. The objectives of our study were to discover genetic polymorphisms in SLC27A6, FABP3, and FABP4, and to test those polymorphisms for associations with milk FA composition. The results showed that after pairwise comparisons between SLC27A6 haplotypes for significantly associated traits, haplotype $\mathrm{H} 3$ was significantly associated with 1.37 weight percentage (wt\%) lower SFA concentration, 0.091 lower SFA:UFA ratio, and $0.17 \mathrm{wt} \%$ lower lauric acid (12:0) concentration, but 1.37 wt\% higher UFA and $1.24 \mathrm{wt} \%$ higher monounsaturated fatty acid (MUFA) concentrations compared with haplotype H1 during the first 3 mo of lactation. Pairwise comparisons between $F A B P 4$ haplotypes for significantly associated traits showed that haplotype $\mathrm{H} 3$ was significantly associated with $1.04 \mathrm{wt} \%$ lower SFA concentration, 0.079 lower SFA:UFA ratio, $0.15 \mathrm{wt} \%$ lower lauric acid (12:0), and $0.27 \mathrm{wt} \%$ lower myristic acid (14:0) concentrations,
\end{abstract}

Received February 17, 2013.

Accepted May 21, 2013.

${ }^{1}$ Current address: 3-228 Lilly Hall, Department of Animal Sciences,

Purdue University, West Lafayette, IN 47907.

${ }^{2}$ Corresponding author: dcbeitz@iastate.edu but $1.04 \mathrm{wt} \%$ higher UFA and $0.91 \mathrm{wt} \%$ higher MUFA concentrations compared with haplotype H1 during the first 3 mo of lactation. Percentages of genetic variance explained by $\mathrm{H} 3$ versus $\mathrm{H} 1$ haplotype substitutions for SLC27A6 and FABP4 ranged from 2.50 to $4.86 \%$ and from 4.91 to $7.22 \%$, respectively. Tag single nucleotide polymorphisms were identified to distinguish haplotypes H3 of SLC27A6 and FABP4 from others encompassing each gene. We found no significant associations between FABP3 haplotypes and milk FA composition. In conclusion, polymorphisms in FABP4 and SLC27A6 can be used to select for cattle producing milk with lower concentrations of SFA and higher concentrations of UFA.

Key words: milk fatty acid, candidate gene, dairy cow, fatty acid transport

\section{INTRODUCTION}

Potentially adverse effects of dietary SFA on plasma cholesterol concentrations and incidence of cardiovascular diseases (CVD) in humans have been known for some time (Noakes et al., 1996; Kris-Etherton and Yu, 1997; Krauss et al., 2000; Mensink et al., 2003; Mozaffarian et al., 2010; Hooper et al., 2011), but uncertainties about deleterious effects of SFA remain (Skeaff and Miller, 2009; Siri-Tarino et al., 2010; Huth and Park, 2012). The ability to control milk FA composition might be important not only to human health but also to the dairy industry for modifying milk technological properties; for example, to produce more-spreadable butter (Kaylegian and Lindsay, 1992; Bobe et al., 2003; Hurtaud et al., 2010). The main objective of our study was to develop genetic markers that would allow for selection of animals producing milk with high concentrations of unsaturated FA (UFA) and low concentrations of SFA. A significant association between fatty acid synthase $(\boldsymbol{F A} \boldsymbol{S N})$ polymorphisms and myristic acid (14:0) concentration in milk was discovered in one of the first studies that determined associations between 
genetic polymorphisms and milk FA composition (Morris et al., 2007). In later studies, a polymorphism in stearoyl-CoA desaturase $(\boldsymbol{S C D})$ was shown to be significantly associated with concentrations of oleic acid (18:1 cis-9) and MUFA, as well as C14 desaturation index (Mele et al., 2007), and a polymorphism in diacylglycerol O-acyltransferase 1 (DGAT1) was shown to be significantly associated with concentrations of palmitic (16:0) and myristic (14:0) acids, SFA:UFA ratio, and concentrations of 18-carbon UFA (Schennink et al., 2007). Two genome-wide association studies using 1,536 SNP and 50,000 SNP chips, respectively, discovered multiple QTL that were significantly associated with concentrations of different FA in milk (Schennink et al., 2009b; Stoop et al., 2009; Bouwman et al., 2011). A recent study from our laboratory showed significant associations between sterol regulatory element-binding transcription factor 1 ( $\boldsymbol{S R} \boldsymbol{E B F 1}$ ) and concentrations of lauric (12:0) and myristic (14:0) acids in milk (Nafikov et al., 2013). Fatty acid heritabilities in our and other studies (Soyeurt et al., 2006; Stoop et al., 2008; Arnould and Soyeurt, 2009; Mele et al., 2009; Bastin et al., 2011; Nafikov et al., 2013) were moderate to high, underlining the advantage of a genetic approach to increase milk UFA concentration over nutritional regulation. The disadvantage of nutritional regulation of milk FA composition is related to the low conversion rate of dietary UFA into milk UFA because of ruminal biohydrogenation (Doreau and Chilliard, 1997).

Milk lipid biosynthesis in the mammary gland involves FA uptake from plasma into mammary epithelial cells followed by FA transport inside the cells. The uptake of long-chain FA from plasma into a cell is mediated by FA transport proteins that are also called solute carrier family 27 (SLC27) proteins (Stahl, 2004; Doege and Stahl, 2006; Bonen et al., 2007). In bovine mammary epithelial cells, SLC27A6 has been found to be the major isoform expressed and its expression was highly upregulated with the onset of lactation (Bionaz and Loor, 2008a,b). After entering a cell, FA have to be either esterified to coenzyme A with a subsequent binding to acyl-CoA binding proteins, or bound to fatty acid binding proteins (FABP) as NEFA (Furuhashi and Hotamisligil, 2008). The most abundant isoforms of FABP expressed in the lactating bovine mammary gland are FABP3 and FABP 4 (Bionaz and Loor, 2008a). Considering the fact that FABP3,FABP4, and $S L$ $C 27 A 6$ are highly expressed in bovine mammary gland during lactation, with FABP3 being the second most abundant transcript among all measured (Bionaz and Loor, 2008a,b), we hypothesized that polymorphisms in SLC27A6, FABP3, and FABP4 genes could affect the selectivity of FA uptake from the blood and FA transport inside the mammary epithelial cells, resulting in differences in milk FA composition. A candidate gene approach was used to test the hypothesis. Animals were genotyped for SNP in SLC27A6, FABP3, and FABP4 and intragenic haplotypes were reconstructed to test their associations with FA concentrations in milk.

\section{MATERIALS AND METHODS}

\section{Animals and Analysis of Milk FA Composition}

Milk sampling was performed once a month throughout a 305-d lactation period during the morning milkings with subsequent storage of samples at $-20^{\circ} \mathrm{C}$ until analyses for FA composition. Data sets for FABP3, $F A B P 4$, and SLC27A6 genes included 3,881, 3,821, and 3,785 milk samples collected from 301, 304, and 291 cows (the daughters of 86,87 , and 83 sires) at the Iowa State University dairy herd, and from 178, 167, and 176 cows (the daughters of 112, 104, and 108 sires) at the Kansas State University dairy herd. Eight of the sires were represented in both herds. All the animals were treated in accordance with guidelines established by the Iowa and Kansas State University Committees on Animal Care. Analysis of milk FA composition by gas chromatography was based on the lipid extraction method with hexane and isopropanol (Hara and Radin, 1978) and the procedure for rapid transmethylation of triacylglycerols (TAG; Christie, 1982) adapted for milk sample analysis (Chouinard et al., 1999) with minor modifications. A detailed description of the procedure was published previously (Nafikov et al., 2013), but the principal steps were as follows. Total lipids were extracted from $25 \mathrm{~mL}$ of milk with hexane:isopropanol $(3: 2, \mathrm{vol} / \mathrm{vol})$. Separation of the lipid-containing hexane phase from the protein-containing water phase was facilitated by addition of $6.7 \%$ solution of sodium sulfate $\left(\mathrm{Na}_{2} \mathrm{SO}_{4}\right)$. Fatty acid methyl esters were produced by addition of methyl acetate and sodium methoxide, and the reaction was terminated after 10 min with oxalic acid. Samples containing FA methyl esters were placed in GC vials and subjected to chromatographic analysis with a Varian 3900 gas chromatograph (Varian Analytical Instruments, Walnut Creek, CA) equipped with CP-8400 auto-sampler, CP-8410 auto-injector, CP-1177 split/splitless injector, and flame ionization detector with helium as a carrier gas. A fused-silica capillary column (Supelco-2560 Capillary Column, 100 $\mathrm{m} \times 0.25 \mathrm{~mm}$ i.d., with $0.2 \mu \mathrm{m}$ film thickness, Supelso, Bellefonte, PA) was used to separate $1 \mu \mathrm{L}$ of FA methyl esters in hexane injected with a split ratio of 50:1. A detailed description of injector and column temperature programs was published previously (Nafikov et al., 2013). Fatty acid peaks were identified by the retention times of separately run FA methyl ester standards (Ma- 
treya LLC, Pleasant Gap, PA) and quantified by the peak area measured with Star Chromatography Workstation version 6 (Varian Analytical Instruments). Concentrations of individual FA were expressed as weight percentages (wt\%) of the total concentration of 39 identified FA in milk, but the data for only 16 FA were used in association tests because of the low concentrations of the remaining FA. As additional traits for association tests, concentrations of SFA, UFA, MUFA, and PUFA, SFA:UFA ratio, C14 [C14 desaturation index $=14: 1 /(14: 0+14: 1)]$, C16 $[$ C16 desaturation index $=$ $16: 1 /(16: 0+16: 1)]$, and C18 [C18 desaturation index $=18: 1 /(18: 0+18: 1)]$ desaturation indices, and elongation index $[(18: 0+18: 1) /(16: 0+16: 1+18: 0+18: 1)]$ were calculated using data for all 39 milk FA analyzed.

\section{SNP Discovery, Genotyping, and Protein Sequence Alignment}

Genomic DNA extraction was performed from the white blood cells of a dairy cow with DNeasy Blood and Tissue Kit (Qiagen Inc., Valencia, CA) according to the manufacturer's instructions. DNA samples from 12 cows, daughters of 12 different sires, were used to sequence FABP3, FABP4, and SLC27A6 (Supplemental Table S1; http://dx.doi.org/10.3168/jds.2013-6703) in exonic and flanking intronic regions using primers designed with Primer3 software (version 0.4.0; Rozen and Skaletsky, 2000) to discover SNP. The PCR reactions were performed in a DNA Engine thermal cycler (BioRad Laboratories, Hercules, CA) with a total reaction volume of $25 \mu \mathrm{L}$ containing $50 \mathrm{ng}$ of genomic DNA and either conventional Taq or HotStar Taq DNA polymerases. The latter was used for the amplification of GCrich DNA regions. An optimal annealing temperature for a particular primer set (Supplemental Table S2; http://dx.doi.org/10.3168/jds.2013-6703) was determined using a PCR temperature gradient. Before sequencing, PCR products were cleaned with ExoSAP-IT (USB Corp., Cleveland, OH) to remove unused primers and deoxynucleotide triphosphates. After sequencing amplified PCR products in both directions, Vector NTI Advance 10 (Life Technologies, Grand Island, NY) was used to discover novel SNP by DNA sequence alignment. Animal genotyping for the discovered SNP was performed with Sequenom MassARRAY platform using $10 \mathrm{ng}$ of genomic DNA dissolved in DNase-free water (Gabriel et al., 2009). Haplotypes spanning each of the studied genes and their frequencies were estimated using the PHASE (version 2.1) program (Stephens et al., 2001; Stephens and Donnelly, 2003). Data containing the best haplotype pairs with a probability $<0.9$ were excluded from further analysis. Only haplotypes with a population frequency $>0.05$ were used in statistical analysis, with the minor frequency haplotypes being pooled into the "other" category. Multiple protein sequence alignment from mammalian species was performed with Clustal X, version 2.0 (Larkin et al., 2007).

\section{Statistical Analysis}

A linear mixed model for longitudinal data was fitted using ASReml software (Gilmour et al., 2009) to test associations between intragenic haplotypes and milk FA composition and to estimate haplotype substitutions for significant associations using the following model:

$$
\begin{aligned}
& Y_{i j k n}=\mu+\operatorname{dim}_{i}+\operatorname{dim}_{i}^{2}+\operatorname{dim}_{i}^{3}+\operatorname{cg}_{j}+\left(\operatorname{dim}_{i} \times \operatorname{cg}_{j}\right) \\
& +\left(\operatorname{dim}_{i}^{2} \times \operatorname{cg}_{j}\right)+\left(\operatorname{dim}_{i}^{3} \times \operatorname{cg}_{j}\right)+\Sigma b_{k} H_{k}+A_{n}+\varepsilon_{i j k n},
\end{aligned}
$$

where $Y_{\mathrm{ijkn}}$ is a response variable; $\mu$ is a general mean; $\operatorname{dim}_{\mathrm{i}}, \operatorname{dim}_{\mathrm{i}}^{2}$, and $\operatorname{dim}_{\mathrm{i}}^{3}$ are covariates describing linear, quadratic, and cubic effects of days in milk on milk FA composition; $\mathrm{cg}_{\mathrm{j}}$ is a fixed effect of a contemporary group $\left(\mathrm{cg}_{\mathrm{j}}=24\right.$ classes $)$ created by the combination of herd ( 2 herds), season of calving (4 seasons: December to February, March to May, June to August, and September to November), and age of calving (3 age groups: group 1: $<2.2$ yr old, group 2: between 2.2 and 4 yr old, and group 3: $>4$ yr old) effects; $\mathrm{H}_{\mathrm{k}}$ is a haplotype effect fitted as a covariate coded as 0,1 , or 2 for the number of copies of each haplotype present in an ani$\mathrm{mal} ; b_{\mathrm{k}}$ is a partial regression coefficient representing the haplotype substitution effect for the kth haplotype as a deviation from the effect of the most frequent haplotype set to zero; $A_{n}$ is the random additive genetic effect of the nth animal; and $\varepsilon_{\mathrm{ijkn}}$ is a residual error. Because milk samples were collected repeatedly from the same cow throughout a 305-d lactation period, a first-order autoregressive covariance structure was used in the statistical model to account for correlations between repeated samples taken on the same cow. The first-order autoregressive covariance structure assumes equal variances and correlations that decline exponentially with an increase in the interval between time points (Littell et al., 1998). The covariance structure was selected based on the biology of the experiment, values of Akaike's and Bayesian information criteria, and the residual log-likelihood (Sawalha et al., 2005). Pedigree information about each cow on the study that included identities of sire, dam, and paternal and maternal grandsires and granddams was used to construct an inverse of additive genetic relationship matrix to fit random additive animal genetic effects into the statistical model. The significance of haplotype effects for each gene was determined separately using an F-test, and adjusted $P$-values for the tests were calculated with 
Table 1. Single nucleotide polymorphisms used for reconstruction of haplotypes in SLC27A6, FABP3, and FABP4 genes ${ }^{1}$

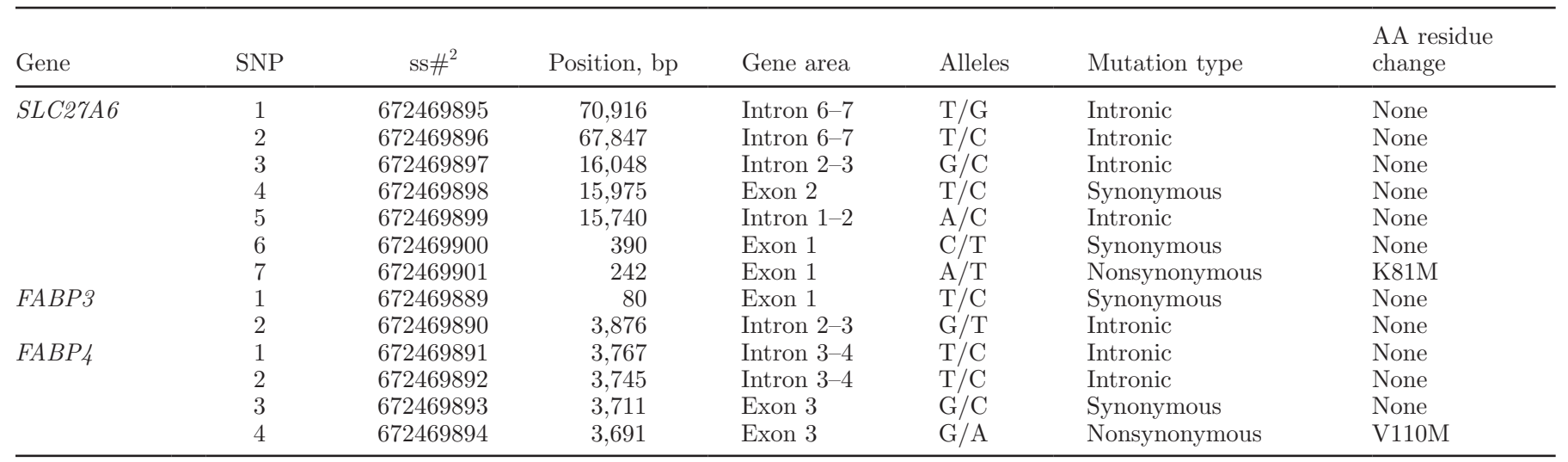

${ }^{1} S L C 27 A 6=$ solute carrier family 27 , isoform $\mathrm{A} 6 ; F A B P 3=$ fatty acid binding protein $3 ; F A B P 4=$ fatty acid binding protein 4.

${ }^{2}$ Submitted SNP (ss) numbers (http://www.ncbi.nlm.nih.gov/SNP/).

Bioconductor "multtest" package in R (Pollard et al., 2011) using the Benjamini and Hochberg (1995) stepup false discovery rate-controlling procedure to account for testing 3 genes at the same time. Significance of the haplotype effects was declared if adjusted $P$-values were $<0.05$. If a haplotype effect for a particular gene was determined to be significant, pairwise comparisons between intragenic haplotypes were performed, and a comparison was declared significant if $P$-value $\leq 0.0167$, $P$-value $\leq 0.0167$, and $P$-value $\leq 0.005$ for $F A B P 3$, $F A B P 4$ and $S L C 27 A 6$, respectively, with these values being determined by the Bonferroni adjustment (0.05 divided by the number of haplotype comparisons; that is, 3, 3, and 10 for FABP3, FABP4 and SLC27A6, respectively) to control type I error rate during multiple comparisons. A comparison of intragenic haplotype sequences within $F A B P 3, F A B P 4$, and SLC27A6 based on the haplotype effects on milk FA composition was used to detect tag SNP for genetic selection. For significantly associated traits, a genetic variance, computed by ASReml software using pedigree information, was used to calculate its percentage explained by a haplotype substitution that had a variance of twice the product of the haplotype frequencies multiplied by the squared estimate of the haplotype substitution.

\section{RESULTS}

In total, 7, 2, and $4 \mathrm{SNP}$ were discovered in exonic and flanking intronic regions of SLC27A6, $F A B P 3$, and FABP4 genes, respectively (Table $1)$. The majority of SNP were intronic but SNP FABP 3:g.80T $>$ C (ss672469889), FABP4:g.3711G $>$ C (ss672469893), SLC27A6:g.390C > T (ss672469900), and SLC27A6:g.15975T >C (ss672469898) were synonymous and SNP FABP4:g.3691G>A (ss672469894, FABP4:p.
Val112Met) and SLC27A6:g.242A $>$ T (ss672469901, SLC27A6:p.Lys81Met) were nonsynonymous. After genotyping animals for these SNP, 5,3 , and 3 haplotypes were reconstructed for $S L C 27 A 6, F A B P 3$, and FABP4, respectively (Table 2 ). The population frequencies of reconstructed haplotypes were above $5 \%$.

The SLC27A6 haplotypes were significantly associated with SFA, UFA, and MUFA concentrations, and SFA:UFA ratio in milk (adjusted $P$-values $=0.018$, $0.018,0.024$, and 0.041 , respectively) when FA data for the first 3 mo of lactation were analyzed (Table 3 ). Haplotypes of SLC27A6 were also significantly associated with lauric acid (12:0) concentration when milk FA data for the entire 305-d lactation and for the periods between both mo 1 and 3 and mo 4 and 10 of lactation were analyzed (adjusted $P$-values $=0.021,0.042$, and 0.045). Pairwise comparisons between haplotype $\mathrm{H} 3$ of SLC27A6 and haplotypes $\mathrm{H} 1$ and $\mathrm{H} 2$, respectively, showed that haplotype $\mathrm{H} 3$ was significantly associated with 1.37 and $1.33 \mathrm{wt} \%$ lower SFA concentration $(P$ values $=0.00021$ and 0.0028$), 0.091$ and 0.095 lower SFA:UFA ratio $(P$-values $=0.00082$ and 0.0039$)$, and 0.17 and $0.19 \mathrm{wt} \%$ lower lauric acid (12:0) concentration $(P$-values $=0.0014$ and 0.0039$)$, but 1.37 and 1.33 wt\% higher UFA ( $P$-values $=0.00021$ and 0.0028$)$ and 1.24 and $1.25 \mathrm{wt} \%$ higher MUFA $(P$-values $=0.00031$ and 0.0025$)$ concentrations when milk FA data for the first 3 mo of lactation were analyzed (Table 4). The significance of SLC27A6 pairwise comparisons was declared with $P$-value $\leq 0.005$ determined by applying the Bonferroni adjustment to account for 10 pairwise comparisons between $S L C 27 A 6$ haplotypes. Significant associations for haplotype $\mathrm{H} 3$ of $S L C 27 A 6$ with 0.14 and $0.20 \mathrm{wt} \%$ lower lauric acid (12:0) concentrations $(P$-values $=0.0009$ and 0.00018$)$ compared with haplotypes $\mathrm{H} 1$ and $\mathrm{H} 2$, respectively, were determined when 
Table 2. Intragenic haplotypes and their frequencies

\begin{tabular}{|c|c|c|c|c|}
\hline Gene $^{1}$ & Haplotype & Sequence $^{2,3}$ & Frequency $^{4}$ & $\begin{array}{l}\text { No. of haploid } \\
\text { genomes }\end{array}$ \\
\hline \multirow[t]{5}{*}{ SLC27A6 } & H1 & $\mathrm{G}_{1} \mathrm{C}_{2} \mathrm{C}_{3} \mathrm{C}_{4} \mathrm{~A}_{5} \mathrm{C}_{6} \mathrm{~A}_{7}$ & 0.44 & 414 \\
\hline & $\mathrm{H} 2$ & $\mathrm{G}_{1} \mathrm{C}_{2} \mathrm{G}_{3} \mathrm{~T}_{4} \mathrm{~A}_{5} \mathrm{C}_{6} \mathrm{~T}_{7}$ & 0.14 & 123 \\
\hline & H3 & $\mathrm{G}_{1} \mathrm{C}_{2} \mathrm{G}_{3} \mathrm{~T}_{4} \mathrm{C}_{5} \mathrm{C}_{6} \mathrm{~T}_{7}$ & 0.11 & 106 \\
\hline & $\mathrm{H} 4$ & $\mathrm{~T}_{1} \mathrm{~T}_{2} \mathrm{C}_{3} \mathrm{C}_{4} \mathrm{~A}_{5} \mathrm{C}_{6} \mathrm{~A}_{7}$ & 0.07 & 62 \\
\hline & H5 & $\mathrm{T}_{1} \mathrm{~T}_{2} \mathrm{G}_{3} \mathrm{~T}_{4} \mathrm{~A}_{5} \mathrm{C}_{6} \mathrm{~A}_{7}$ & 0.18 & 176 \\
\hline \multirow[t]{3}{*}{ FABP3 } & H1 & $\mathrm{T}_{1} \mathrm{G}_{2}$ & 0.74 & 697 \\
\hline & $\mathrm{H} 2$ & $\mathrm{~T}_{1} \mathrm{~T}_{2}$ & 0.07 & 63 \\
\hline & H3 & $\mathrm{C}_{1} \mathrm{G}_{2}$ & 0.20 & 198 \\
\hline \multirow[t]{3}{*}{$F A B P 4$} & H1 & $\mathrm{C}_{1} \mathrm{C}_{2} \mathrm{C}_{3} \mathrm{G}_{4}$ & 0.50 & 459 \\
\hline & $\mathrm{H} 2$ & $\mathrm{~T}_{1} \mathrm{~T}_{2} \mathrm{G}_{3} \mathrm{G}_{4}$ & 0.27 & 246 \\
\hline & $\mathrm{H} 3$ & $\mathrm{~T}_{1} \mathrm{~T}_{2} \mathrm{G}_{3} \underline{\mathrm{A}}_{4}$ & 0.24 & 237 \\
\hline
\end{tabular}

milk FA composition data for the period between mo 1 and 3 of lactation were analyzed (Table 4). Percentages of genetic variance explained by SLC27A6 haplotype substitutions were between 0.62 and $4.86 \%$ (Table 4). The highest percentages, ranging from $1.60 \%$ for capric acid (10:0) to $4.86 \%$ for MUFA, were observed for haplotype $\mathrm{H} 3$ versus haplotype $\mathrm{H} 1$ of $S L C 27 A 6$. Contribution of haplotype $\mathrm{H} 3$ versus haplotype $\mathrm{H} 2$ of $S L C 27 A 6$ to genetic variance was smaller and ranged from 0.76 to $1.57 \%$.

Haplotypes of $F A B P 4$ were significantly associated with concentrations of SFA, UFA, and MUFA, and SFA:UFA ratio, when milk FA data for the entire 305-d lactation (adjusted $P$-values $=0.027,0.027,0.042$, and 0.042 ) and the first 3 mo of lactation (adjusted $P$-values $=0.009,0.009,0.012$, and 0.006) were analyzed (Table 5 ). The significant associations between $F A B P 4$ haplotypes and concentrations of lauric (12:0) and myristic (14:0) acids (adjusted $P$-values $=0.009$ and 0.012 ) were detected when milk FA data for the first 3 mo of lactation were analyzed. Pairwise comparisons between $F A B P$ \& haplotypes revealed that haplotype H3 was significantly associated with $0.70 \mathrm{wt} \%$ lower SFA concentration and 0.051 smaller SFA:UFA ratio $(P$-values $=$ 0.0011 and 0.0017 ), but $0.70 \mathrm{wt} \%$ higher UFA and 0.60 wt\% higher MUFA concentrations $(P$-values $=0.0011$ and 0.0017) compared with haplotype $\mathrm{H} 1$ when milk FA data for the entire 305-d lactation were analyzed (Table 6). The significance of FABP4 pairwise comparisons was declared with $P$-value $\leq 0.017$ determined by applying the Bonferroni adjustment to account for 3 pairwise comparisons between $F A B P 4$ haplotypes. Pairwise comparisons between $F A B P_{4}$ haplotypes tested over the first 3 mo of lactation showed that haplotype $\mathrm{H} 3$ of $F A B P 4$ was significantly associated with 1.04 wt\% lower SFA concentration, 0.079 lower SFA:UFA ratio, $0.15 \mathrm{wt} \%$ lower lauric (12:0), and $0.27 \mathrm{wt} \%$ lower myristic (14:0) acid concentrations (adjusted $P$-values $=0.00036,0.00025,0.00069$, and 0.0022), but $1.04 \mathrm{wt} \%$ higher UFA and $0.91 \mathrm{wt} \%$ higher MUFA concentrations (adjusted $P$-values $=0.00036$ and 0.00067 ) compared with haplotype H1. The comparisons between haplotypes $\mathrm{H} 2$ and $\mathrm{H} 1$ of $F A B P 4$ performed using milk FA data for the first 3 mo of lactation showed that haplotype $\mathrm{H} 2$ was also significantly associated with 0.096 wt\% lower lauric (12:0) and $0.25 \mathrm{wt} \%$ lower myristic (14:0) acid concentrations (adjusted $P$-values $=0.014$ and 0.0032). Percentages of genetic variance explained by FABP 4 haplotype substitutions were between 1.80 and $7.22 \%$ when only statistically significant haplotype substitutions were considered (Table 6). The highest percentages ranging from $3.90 \%$ for myristic acid (14:0) to $7.22 \%$ for SFA:UFA ratio were observed for haplotype $\mathrm{H} 3$ versus haplotype $\mathrm{H} 1$ of $F A B P 4$ when data for the first 3 mo of lactation were analyzed. We found no significant associations between FABP3 haplotypes and any of the studied traits (Supplemental Table S3; http://dx.doi.org/10.3168/jds.2013-6703).

A nonsynonymous FABP4:g.3691G >A (ss672469894, FABP4:p.Val110Met) mutation and an intronic SLC27A6:g.15740A >C (ss672469899) mutation were selected as tag SNP to distinguish haplotype H3 of FABP4 and haplotype H3 of SLC27A6 from the other haplotypes spanning each gene, respectively (Table 2). Amino acid residue 110 of FABP4 is part of the AA sequence that belongs to lipocalin/cytosolic fatty acidbinding protein family domain. An alignment of FABP4 protein sequences from different mammalian species (data not shown) did not indicate that FABP4:p. Val110Met mutation was well conserved among the 
Table 3. Results of F-test for solute carrier family 27, isoform A6 (SLC27A6) haplotypes on milk FA composition

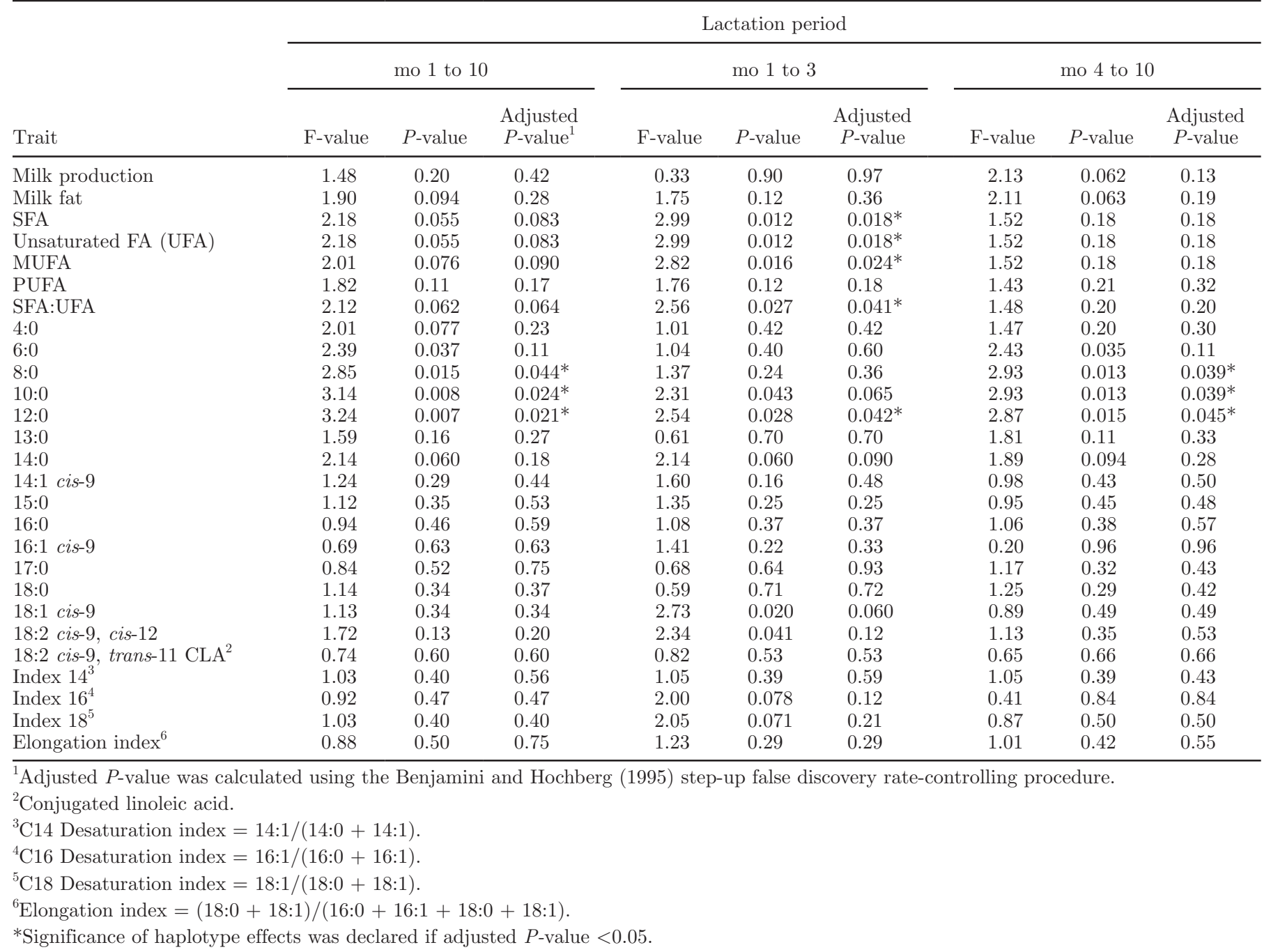

species. The SLC27A6:p.Lys81Met mutation caused by SNP SLC27A6:g.242A > T (ss672469901) was a part of acetyl-CoA synthetase-like superfamily domain (71-600 AA residues) that did not contain the SLC27A6 transmembrane domain (12-34 AA residues).

\section{DISCUSSION}

Milk FA composition data from the 305-d lactation and from the first 3 and last 7 mo of lactation were separately tested for associations with polymorphisms in our candidate genes. We tested different stages of lactation because the contribution of de novo lipogenesis toward milk lipid biosynthesis in mammary gland of dairy cattle is higher during mid and late lactation compared with the first 3 mo of lactation, when the contribution of lipolysis from adipose tissue toward milk lipid biosynthesis is greater (McNamara, 1989).
This phenomenon might explain why heritabilities of milk FA are higher during mid and late lactation compared with during the first 3 mo of lactation (Bastin et al., 2011; Gross et al., 2011; Nafikov et al., 2013).

The SLC27A6 has been characterized as a membraneassociated FA binding protein that participates in FA transport across a cell membrane and is expressed primarily in heart muscle tissue (Gimeno et al., 2003). It has been shown that $S L C 27 A 6$ is also expressed in bovine mammary epithelial cells and is the most abundant transcript among SLC27A isoforms, reaching a peak of expression $15 \mathrm{~d}$ after parturition and declining in mRNA abundance thereafter throughout the lactation (Bionaz and Loor, 2008a,b). The mechanism of SLC27A6-mediated FA transport across a cell membrane is not established but, in vitro, SLC27A6 has the ability to transport palmitic (16:0), oleic (18:1 cis-9), linoleic (18:2 cis-9, cis-12), and caprylic (8:0) acids with 
Table 4. Pairwise comparisons of solute carrier family 27, isoform A6 (SLC27A6) haplotypes on milk FA composition ${ }^{1}$

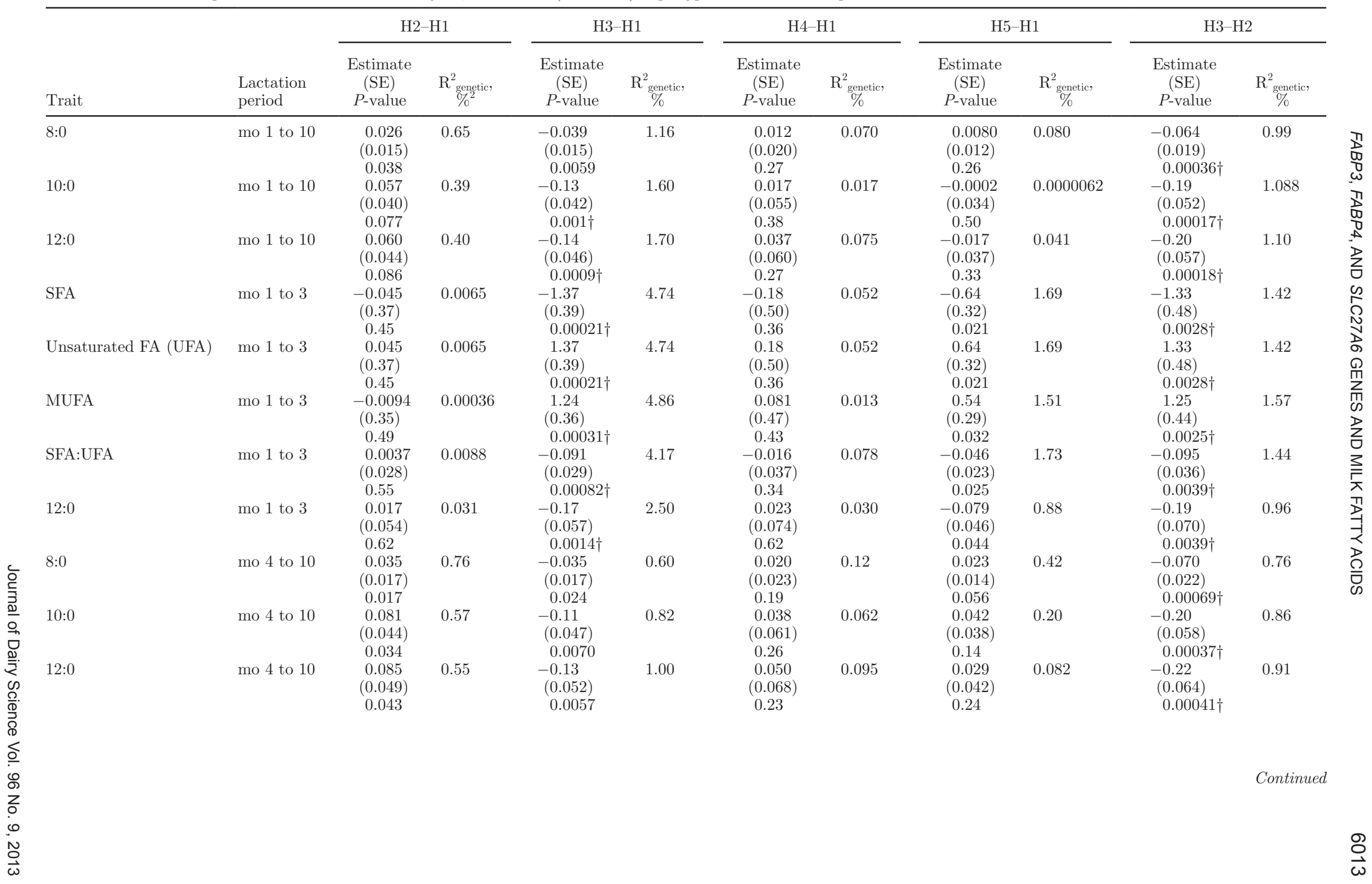




\begin{tabular}{|c|c|c|c|c|c|c|c|c|c|c|c|}
\hline \multirow[b]{2}{*}{ Trait } & \multirow[b]{2}{*}{$\begin{array}{l}\text { Lactation } \\
\text { period }\end{array}$} & \multicolumn{2}{|c|}{$\mathrm{H} 2-\mathrm{H} 1$} & \multicolumn{2}{|c|}{ H3-H1 } & \multicolumn{2}{|c|}{$\mathrm{H} 4-\mathrm{H} 1$} & \multicolumn{2}{|c|}{$\mathrm{H} 5-\mathrm{H} 1$} & \multicolumn{2}{|c|}{$\mathrm{H} 3-\mathrm{H} 2$} \\
\hline & & $\begin{array}{c}\text { Estimate } \\
\text { (SE) } \\
P \text {-value }\end{array}$ & $\mathrm{R}_{\substack{\text { genetic } \\
\%^{2}}}^{2}$ & $\begin{array}{c}\text { Estimate } \\
\text { (SE) } \\
P \text {-value }\end{array}$ & $\mathrm{R}_{\text {genetic }}^{2}$, & $\begin{array}{c}\text { Estimate } \\
\text { (SE) } \\
P \text {-value }\end{array}$ & $\begin{array}{l}\mathrm{R}_{\text {genetic }}^{2}, \\
\%\end{array}$ & $\begin{array}{c}\text { Estimate } \\
\text { (SE) } \\
P \text {-value }\end{array}$ & $\begin{array}{c}\mathrm{R}_{\text {genetic }}^{2}, \\
\%\end{array}$ & $\begin{array}{c}\text { Estimate } \\
\text { (SE) } \\
P \text {-value }\end{array}$ & $\mathrm{R}_{\frac{\text { genetic }}{2}}$ \\
\hline & & \multicolumn{2}{|c|}{$\mathrm{H} 4-\mathrm{H} 2$} & \multicolumn{2}{|c|}{$\mathrm{H} 5-\mathrm{H} 2$} & \multicolumn{2}{|c|}{$\mathrm{H} 4-\mathrm{H} 3$} & \multicolumn{2}{|c|}{$\mathrm{H} 5-\mathrm{H} 3$} & \multicolumn{2}{|c|}{$\mathrm{H} 5-\mathrm{H} 4$} \\
\hline $8: 0$ & mo 1 to 10 & $\begin{array}{c}-0.013 \\
(0.022)\end{array}$ & & $\begin{array}{c}-0.018 \\
(0.017)\end{array}$ & & $\begin{array}{c}0.051 \\
(0.024)\end{array}$ & & $\begin{array}{c}0.047 \\
(0.017)\end{array}$ & & $\begin{array}{c}-0.0044 \\
(0.021)\end{array}$ & \\
\hline & & 0.27 & 0.026 & 0.14 & 0.13 & 0.017 & 0.31 & $0.0036^{\dagger}$ & 0.69 & 0.42 & 0.0038 \\
\hline 10:0 & mo 1 to 10 & $\begin{array}{c}-0.040 \\
(0.061)\end{array}$ & 0.031 & $\begin{array}{c}-0.057 \\
(0.046)\end{array}$ & 0.16 & $\begin{array}{l}0.15 \\
(0.065)\end{array}$ & 0.34 & $\begin{array}{l}0.13 \\
(0.047) \\
0.0031+\end{array}$ & 0.65 & $\begin{array}{c}-0.017 \\
(0.059) \\
0.39\end{array}$ & 0.0071 \\
\hline $12: 0$ & mo 1 to 10 & $\begin{array}{c}0.05 \\
-0.023 \\
(0.067)\end{array}$ & 0.0093 & $\begin{array}{c}0.11 \\
-0.076 \\
(0.050)\end{array}$ & 0.26 & $\begin{array}{l}0.018 \\
0.18 \\
(0.072)\end{array}$ & 0.45 & $\begin{array}{l}0.0031 \mid \\
0.13 \\
(0.052)\end{array}$ & 0.60 & $\begin{array}{c}0.09 \\
-0.053 \\
(0.064)\end{array}$ & 0.063 \\
\hline SFA & mo 1 to 3 & $\begin{array}{c}0.37 \\
-0.13 \\
(0.56) \\
0.41\end{array}$ & 0.0086 & $\begin{array}{c}0.063 \\
-0.60 \\
(0.42) \\
0.080\end{array}$ & 0.47 & $\begin{array}{l}0.0060 \\
1.20 \\
(0.60) \\
0.024\end{array}$ & 0.58 & $\begin{array}{l}0.0071 \\
0.73 \\
(0.44) \\
0.047\end{array}$ & 0.55 & $\begin{array}{c}0.20 \\
-0.46 \\
(0.54) \\
0.20\end{array}$ & 0.14 \\
\hline Unsaturated FA (UFA) & mo 1 to 3 & $\begin{array}{c}0.13 \\
(0.56) \\
0.41\end{array}$ & 0.0086 & $\begin{array}{c}0.60 \\
(0.42) \\
0.080\end{array}$ & 0.47 & $\begin{array}{c}-1.20 \\
(0.60) \\
0.024\end{array}$ & 0.58 & $\begin{array}{c}-0.73 \\
(0.44) \\
0.047\end{array}$ & 0.55 & $\begin{array}{c}0.46 \\
(0.54) \\
0.20\end{array}$ & 0.14 \\
\hline MUFA & mo 1 to 3 & $\begin{array}{c}0.091 \\
(0.52) \\
0.43\end{array}$ & 0.0053 & $\begin{array}{c}0.55 \\
(0.39) \\
0.080\end{array}$ & 0.50 & $\begin{array}{c}-1.16 \\
(0.56) \\
0.020\end{array}$ & 0.68 & $\begin{array}{c}-0.69 \\
(0.40) \\
0.043\end{array}$ & 0.62 & $\begin{array}{c}0.46 \\
(0.50) \\
0.18\end{array}$ & 0.17 \\
\hline SFA:UFA & mo 1 to 3 & $\begin{array}{c}-0.019 \\
(0.041) \\
0.32\end{array}$ & 0.038 & $\begin{array}{c}-0.050 \\
(0.032) \\
0.059\end{array}$ & 0.65 & $\begin{array}{c}0.075 \\
(0.045) \\
0.95\end{array}$ & 0.46 & $\begin{array}{c}0.045 \\
(0.032) \\
0.92\end{array}$ & 0.42 & $\begin{array}{c}-0.030 \\
(0.040) \\
0.23\end{array}$ & 0.12 \\
\hline 12:0 & mo 1 to 3 & $\begin{array}{c}0.0064 \\
(0.082) \\
0.53\end{array}$ & 0.00072 & $\begin{array}{c}-0.096 \\
(0.062) \\
0.061\end{array}$ & 0.41 & $\begin{array}{c}0.19 \\
(0.088) \\
0.99\end{array}$ & 0.51 & $\begin{array}{c}0.091 \\
(0.064) \\
0.92\end{array}$ & 0.29 & $\begin{array}{c}-0.10 \\
(0.079) \\
0.099\end{array}$ & 0.24 \\
\hline $8: 0$ & mo 4 to 10 & $\begin{array}{c}-0.015 \\
(0.026) \\
0.28\end{array}$ & 0.022 & $\begin{array}{c}-0.013 \\
(0.019) \\
0.26\end{array}$ & 0.043 & $\begin{array}{c}0.055 \\
(0.027) \\
0.023\end{array}$ & 0.24 & $\begin{array}{c}0.057 \\
(0.020) \\
0.0020 \dagger\end{array}$ & 0.65 & $\begin{array}{c}0.0026 \\
(0.025) \\
0.46\end{array}$ & 0.00086 \\
\hline 10:0 & mo 4 to 10 & $\begin{array}{c}-0.043 \\
(0.068)\end{array}$ & 0.025 & $\begin{array}{c}-0.039 \\
(0.051)\end{array}$ & 0.054 & $\begin{array}{l}0.020 \\
0.15 \\
(0.073)\end{array}$ & 0.24 & $\begin{array}{l}0.16 \\
(0.053)\end{array}$ & 0.71 & $\begin{array}{c}0.0036 \\
(0.066)\end{array}$ & 0.00023 \\
\hline $12: 0$ & mo 4 to 10 & $\begin{array}{c}-0.035 \\
(0.076) \\
0.32\end{array}$ & 0.015 & $\begin{array}{c}-0.056 \\
(0.057) \\
0.16\end{array}$ & 0.097 & $\begin{array}{c}0.18 \\
(0.081) \\
0.013\end{array}$ & 0.31 & $\begin{array}{l}0.16 \\
(0.059) \\
0.0032 \dagger\end{array}$ & 0.62 & $\begin{array}{c}-0.021 \\
(0.073) \\
0.39\end{array}$ & 0.0068 \\
\hline
\end{tabular}

${ }^{1} \mathrm{H}_{\mathrm{a}}-\mathrm{H}_{\mathrm{b}}=$ a pair of haplotypes for which a haplotype substitution effect was evaluated. The first value in the cell is an estimate of the haplotype substitution effect (expressed in $\mathrm{wt} \%$ ) for all individual FA; the second value (in parentheses) is SE of an estimate of the haplotype substitution effect expressed in the same units as the estimate; the third value is a $P$-value.

${ }^{2} \mathrm{R}^{2}=$ percentage of genetic variance explained by a haplotype substitution effect.

$\dagger$ Significance was declared if $P$-value was $\leq 0.005$ after applying Bonferroni adjustment $(0.05$ divided by the number of comparisons, which was 10$)$. 
Table 5. Results of F-test for fatty acid binding protein 4 (FABP 4) haplotypes on milk FA composition

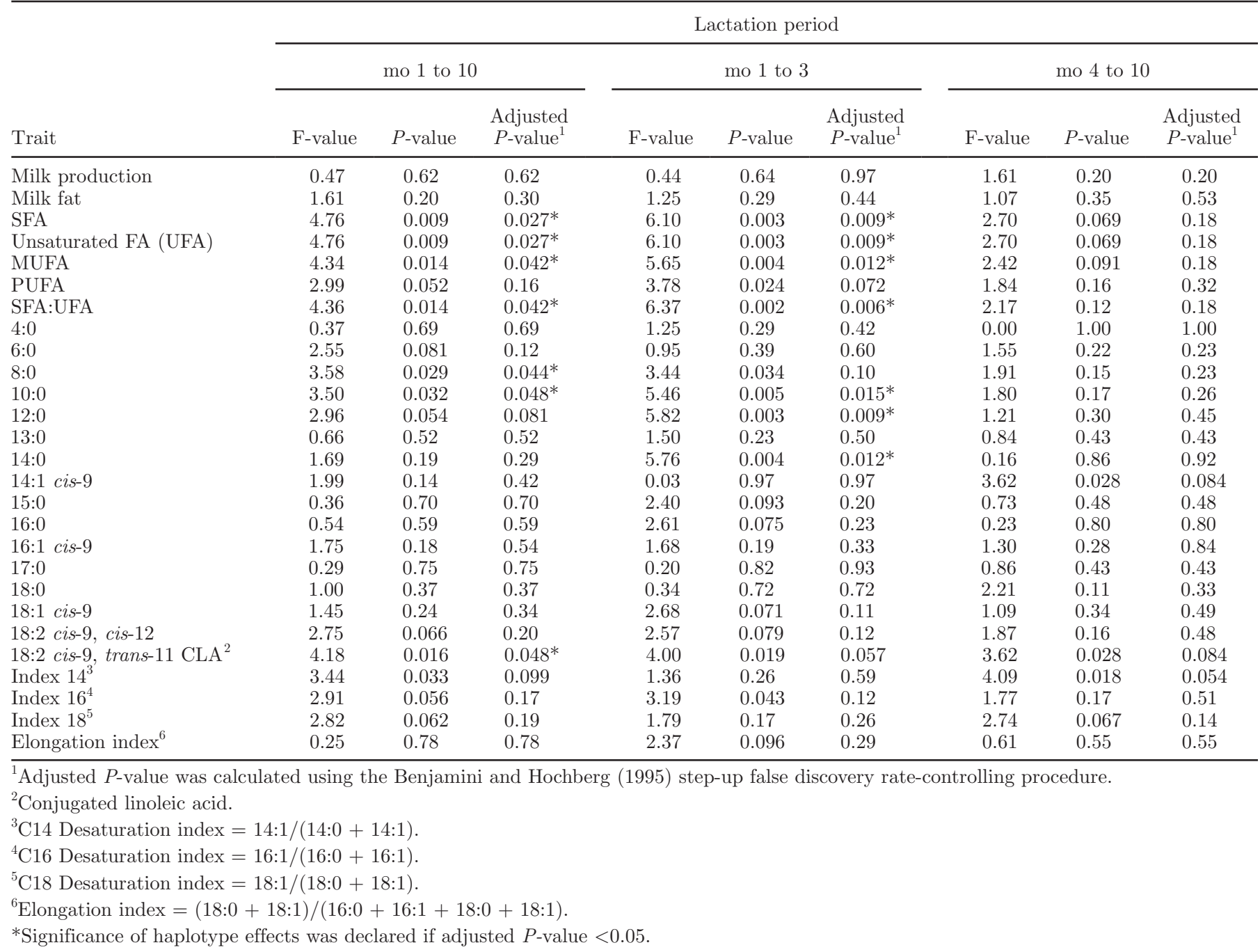

decreasing affinities (Gimeno et al., 2003). Moreover, at least in heart muscle, SLC27A6 is targeted to the parts of cell membrane that make direct contact with the microvasculature, underlying a potential involvement of SLC27A6 in transporting NEFA from blood into mammary epithelial cells for milk TAG biosynthesis. In our study, genetic polymorphisms in SLC27A6 were significantly associated with concentrations of SFA, UFA, and MUFA, SFA:UFA ratio, and the concentration of lauric (12:0) acid in milk mainly during the first 3 mo of lactation (Table 3), when the majority of long- and medium-chain FA in milk come from TAG hydrolysis in adipose tissue (McNamara, 1989) and the expression of SLC27A6 in bovine mammary epithelial cells reaches its highest rate for the entire lactation (Bionaz and Loor, 2008a). Genotype-dependent changes in the specificity of SLC27A6 for transporting FA across a cell membrane might be responsible for the differences in milk FA composition observed in our study. Association of lauric (12:0) acid concentration in milk with SLC27A6 polymorphisms, on the other hand, might be explained by alterations in intracellular FA concentrations in bovine mammary gland caused by changes in FA specificity of SLC27A6 transporter. Pairwise comparisons between SLC27A6 haplotypes showed that haplotype $\mathrm{H} 3$ was the most desirable when selecting for milk with lower SFA and higher UFA concentrations because, compared with haplotypes $\mathrm{H} 1$ and $\mathrm{H} 2$, haplotype H3 was always significantly associated with those traits (Table 4). The phenotypic changes associated with haplotype $\mathrm{H} 3$ of SLC27A6 were not caused by SLC27A6:g.242A > T (ss672469901, SLC27A6:p.Lys$81 \mathrm{Met}$ ) mutation because haplotype $\mathrm{H} 2$ of $S L C 27 A 6$ had the same mutation present but was associated with a completely different milk FA composition compared with haplotype H3. A tag SNP that distinguishes 
Table 6. Pairwise comparisons of fatty acid binding protein 4 (FABP4) haplotypes on milk FA composition ${ }^{1}$

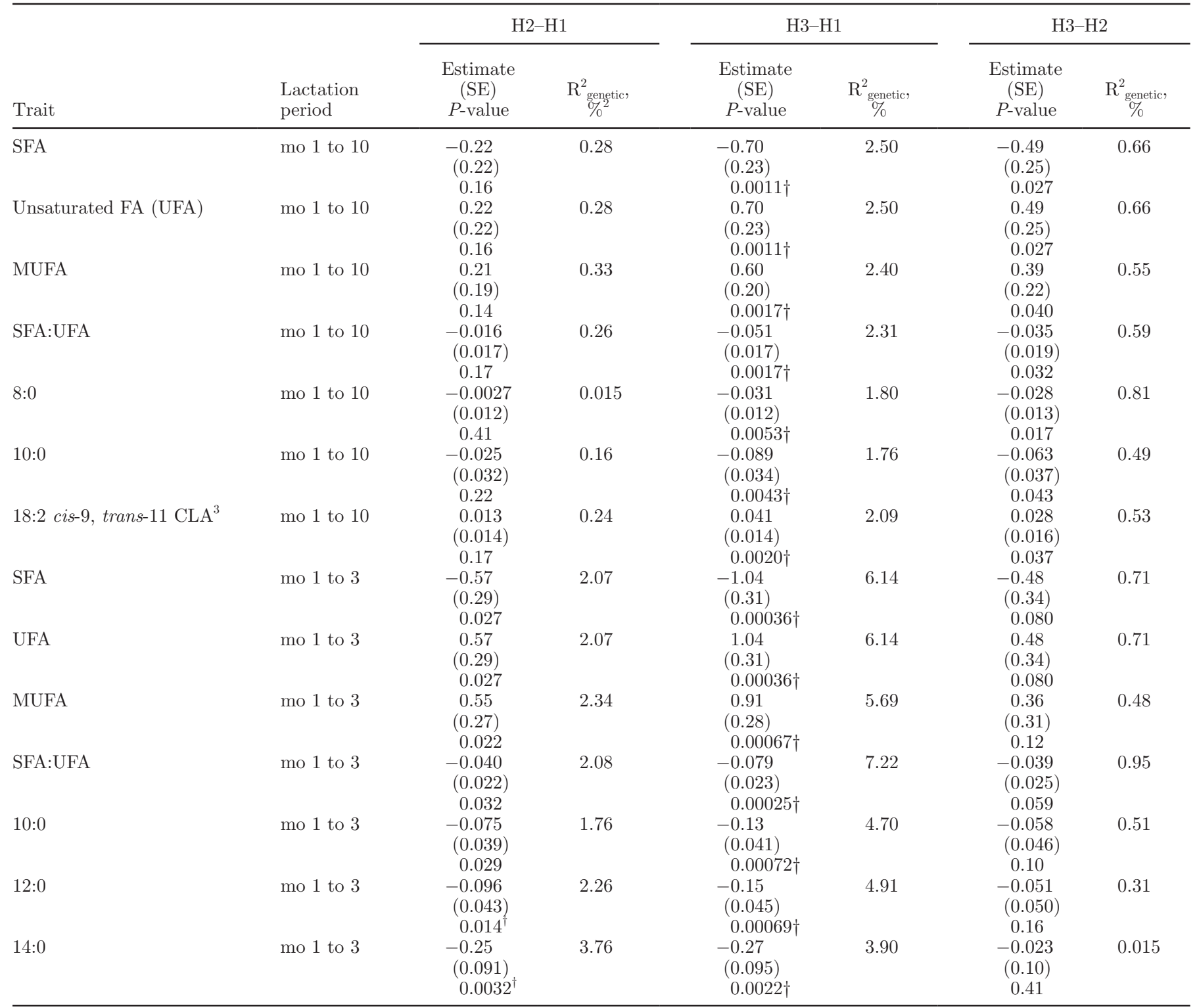

${ }^{1} \mathrm{H}_{\mathrm{a}}-\mathrm{H}_{\mathrm{b}}=$ a pair of haplotypes for which a haplotype substitution effect was evaluated. The first value in the cell is an estimate of the haplotype substitution effect (expressed in wt\%) for all individual FA; the second value (in parentheses) is SE of an estimate of the haplotype substitution effect expressed in the same units as the estimate; the third value is a $P$-value.

${ }^{2} \mathrm{R}^{2}=$ percentage of genetic variance explained by a haplotype substitution effect.

${ }^{3}$ Conjugated linoleic acid.

$\dagger$ Significance was declared if $P$-value was $\leq 0.0167$ after applying the Bonferroni adjustment (0.05 divided by the number of comparisons, which was 3$)$.

haplotype $\mathrm{H} 3$ from other SLC27A6 haplotypes was an intronic SNP SLC27A6:g.15740A >C (ss672469899) that might be in linkage disequilibrium with a nonsynonymous mutation of $S L C 27 A 6$ responsible for the observed phenotypes.

From the discovery of $F A B P 4$ in mice (Hotamisligil et al., 1996) and the association of $F A B P 4$ genetic polymorphisms with plasma TAG concentrations in humans (Tuncman et al., 2006), numerous studies have looked at polymorphisms in $F A B P 4$ with regard to different lipid-associated traits in farm animals. In particular, polymorphisms in FABP4 were significantly associated with back fat and intramuscular fat thickness in beef cattle (Cho et al., 2008; Barendse et al., 2009), intramuscular fat content in pigs (Gerbens et al., 1998), and the amount of abdominal adipose tissue in chickens (Wang et al., 2009). The only study that reported a significant association of $F A B P 4$ genetic polymor- 
phisms with palmitoleic acid (16:1 cis-9) concentration in adipose tissue was conducted in beef cattle (Hoashi et al., 2008). The function of FABP4 protein in the bovine mammary epithelial cells might be related to the intracellular transport of FA to the endoplasmic reticulum, a site of milk TAG biosynthesis, after FA have been released from adipose tissue, transported to the mammary gland, and taken up by the mammary epithelial cells. The mRNA abundance of FABP 4 that was measured in biopsy samples from bovine mammary gland throughout lactation increased at the beginning of lactation, peaked at $60 \mathrm{~d}$ after parturition, and declined thereafter (Bionaz and Loor, 2008a). Such a trend of $F A B P 4$ expression, in combination with significant associations between $F A B P 4$ haplotypes and concentrations of SFA, UFA, MUFA, and SFA:UFA ratio in milk determined for the first 3 mo of lactation (Table 5), highlights the importance of FABP4 protein function in earlier lactation when lipolysis from adipose tissue is the main source of FA for milk TAG biosynthesis (McNamara, 1989). The significant association of FABP 4 haplotypes with myristic acid (14:0) concentration (Table 5) can also be explained by the role of $F_{A B P} 4$ in transporting $\mathrm{FA}$ hydrolyzed from adipose tissue TAG for milk TAG biosynthesis inside mammary epithelial cells, but capric (10:0) and lauric (12:0) acids mainly come from de novo FA biosynthesis in the mammary gland, implying that $F A B P 4$ might play a role in transporting those FA as well. Pairwise comparisons between FABP4 haplotypes showed that haplotype $\mathrm{H} 3$ is the most desirable to produce milk with lower concentration of SFA and higher concentration of UFA compared with haplotypes H1 and H2 (Table 6). The tag SNP FABP4:g.3691G>A (ss672469894) can be used to distinguish haplotype $\mathrm{H} 3$ from the other FABP 4 haplotypes. Fatty acid-binding protein 4 belongs to a family of intracellular FABP that are about $15 \mathrm{kDa}$ in size and vary greatly in AA sequences $(20$ to $70 \%$ ) but still have well-preserved tertiary structure consisting of 10 antiparallel $\beta$-strands organized into a $\beta$-barrel structure formed by 2 antiparallel $\beta$-sheets with hydrophobic ligand-binding site formed inside the barrel (Vogel Hertzel and Bernlohr, 2000). Even though the FABP4:g.3691G>A (ss672469894) mutation is not conserved among mammalian species, it still can affect FABP4 binding specificity for certain FA and be responsible for the observed phenotypic effects of haplotype $\mathrm{H} 3$ of $F A B P 4$.

Being one of the most abundant mRNA transcripts among all FABP isoforms, FABP3 is highly expressed during lactation in bovine mammary gland (Bionaz and Loor, 2008a,b). A similar high level of expression of FABP3 during lactation was also observed in murine mammary gland (Rudolph et al., 2007). The discovery of FABP3 protein in mammary gland was related to the identification of a mammary-derived growth inhibitor (MDGI) that turned out to be a mixture of FABP3 and FABP4 proteins (Bohmer et al., 1987; Specht et al., 1996). The MDGI inhibited the growth of human breast cancer cells (Huynh et al., 1995). Although FABP3 protein is highly expressed in mammary gland during cell differentiation and formation of ductal structures at the onset of lactation (Binas et al., 1992), the requirement of FABP3 for mammary tissue development and function is not well established (Binas et al., 1995; Clarke et al., 1997). The deletion of FABP3 gene in mice, however, does not have any effect on mammary gland development or function (Clark et al., 2000), but the knockout mice have lower concentrations of oleic acid (18:1 cis-9) in milk compared with the wild-type mice. Nevertheless, we were not able to determine any significant associations between FABP3 haplotypes and milk FA composition (Supplemental Table S3; http:// dx.doi.org/10.3168/jds.2013-6703). The results are consistent with the primary role of FABP3 in transporting FA inside a cell for $\beta$-oxidation (Furuhashi and Hotamisligil, 2008).

The role of FABP1, SLC27A1, and cluster of differentiation 36 (CD36) in FA uptake into the mammary gland of lactating rats was studied using dietary conjugated linoleic acid (CLA; Gutgesell et al., 2009). It was determined that dietary CLA fed to rats decreased the concentrations of medium-chain SFA and palmitic acid (16:0) in milk. The change in milk FA concentrations was accompanied by a decrease in the mRNA abundance of FABP1, SLC27A1, and CD36 in the mammary gland and by an increase in blood NEFA concentrations (Gutgesell et al., 2009). The above results clearly indicate that changes in the functionality of FA transporters can affect milk FA composition.

As it was shown by us (Nafikov et al., 2013) and others (Bastin et al., 2011; Gross et al., 2011), milk FA heritabilities change throughout a lactation, indicating the involvement of different sets of genes in the regulation of milk FA composition during different parts of lactation. The SREBF1, known to regulate lipid biosynthesis (Horton et al., 2002), was significantly associated with milk FA concentrations during a period between 4 and 10 mo of lactation (Nafikov et al., 2013) when lipogenesis is the major source of FA for milk TAG biosynthesis (McNamara, 1989). Polymorphisms in SLC27A6 and FABP4, on the other hand, were significantly associated with milk FA concentrations primarily during the first 3 mo of lactation when the contribution of lipolysis in adipose tissue toward milk TAG biosynthesis was the greatest and increased expression of SLC27A6 and FABP4 was necessary to facilitate FA uptake by mammary epithelial cells from 
plasma and transport FA inside the cells. Fatty acid associations with polymorphisms in SREBF1, SLC27A6, and $F A B P 4$ were also dependent on the specificity of each of those genes. Significant associations of $S R E B F 1$ with concentrations of lauric (12:0) and myristic (14:0) acids, mainly the products of de novo lipogenesis, confirm the role of $S R E B F 1$ in the regulation of lipogenesis. Likewise, significant associations of both SLC27A6 and FABP \& with concentrations of SFA, UFA, and MUFA, composed of major FA found in adipose tissue, indicate the importance of those genes in the regulation of uptake and transport of FA released through lipolysis in adipose tissue toward milk TAG biosynthesis. The size of haplotype substitutions and a percentage of genetic variance explained by those substitutions were higher for FABP4 and SLC27A6 associations with lauric acid (12:0) concentration and lower for $F A B P 4$ association with myristic acid (14:0) concentration compared with SREBF1. However, the periods of lactation for which the significant associations were determined were different between $S R E B F 1$ and the 2 other genes.

Comparisons between genetic association studies on milk FA composition, especially with respect to changes in FA concentrations for a particular association and a percentage of genetic variance explained by it, are difficult to make because of (1) differences in the analysis of milk FA composition, performed either by GC method or the less precise infrared spectroscopic method; (2) collection of milk samples from each cow, done either multiple times throughout the entire 305-d lactation period, as in our studies, or once or twice for the entire lactation; and (3) statistical analysis of data, performed using different statistical models. In addition to FABP 4 data presented in this paper, associations of genetic polymorphisms with myristic acid (14:0) concentration in milk have been shown for FASN (Morris et al., 2007; Schennink et al., 2009a), DGAT1 (Schennink et al., 2007), SCD (Schennink et al., 2008), signal transducer and activator of transcription 5A (STAT5A; Schennink et al., 2009a), and SREBF1 (Nafikov et al., 2013). Associations of genetic polymorphisms with milk lauric acid (12:0) concentration shown for $S C D$ (Schennink et al., 2008) and SREBF1 (Nafikov et al., 2013) and with capric acid (10:0) concentration shown for $S C D$ (Schennink et al., 2008) were also determined in our study for both SLC27A6 and FABP4. An earlier study on SCD polymorphism and milk FA composition (Mele et al., 2007), however, did not find any significant associations for lauric (12:0) and myristic (14:0) acid concentrations in milk reported by Schennink et al. (2008). Associations for MUFA concentration and SFA:UFA ratio in milk, determined in our study for both $S L C 27 A 6$ and $F A B P 4$, were reported previously for $S C D$ and $D G A T 1$, respectively (Mele et al., 2007; Schennink et al., 2007).
Percentages of genetic variance explained by the DGAT1 K232A polymorphism ranged from $1 \%$ for a group of short- and medium-chain FA with 4 to 12 carbon atoms and for stearic acid (18:0) to $23 \%$ for myristic acid (14:0), $40 \%$ for palmitic acid (16:0), and $53 \%$ for oleic acid (18:1 cis-9; Schennink et al., 2007). Highly significant associations of the DGAT1 K232A polymorphism with milk FA composition reported by Schennink et al. (2007), however, do not exclude a possibility that the percentage of genetic variance explained by those associations might be slightly overestimated. Even in genome-wide association studies conducted in humans using large numbers of genetic markers, 32 and 18 loci that defined quantitative traits such as BW index and plasma cholesterol concentrations, respectively, were able to explain only 2 to $4 \%$ and 5 to $6 \%$ of genetic variance, respectively (Stranger et al., 2011). As was shown for myristic acid (14:0) concentration in milk, polymorphisms in SREBF1 accounted for up to $4.53 \%$ of genetic variance (Nafikov et al., 2013). In the current study, the largest percentages of genetic variance explained by the polymorphisms in SLC27A6 and $F A B P$ 4, respectively, were $4.86 \%$ for MUFA concentration and $7.22 \%$ for SFA:UFA ratio in milk. Despite not very high percentages of genetic variance explained by the genetic polymorphisms in our study, the efficiency of selection will still be high because it depends mainly on heritability values for the traits (Lande and Thompson, 1990), which in our case were moderate to high (Nafikov et al., 2013).

In a genome-wide screen for milk FA QTL using a 50,000-SNP chip (Bouwman et al., 2011), no significant QTL were identified in chromosomal regions near 26.3 Mbp on BTA7 and 46.8 Mbp on BTA14, where SLC27A6 and FABP4 are located, respectively. The QTL for myristic acid (14:0) concentration in milk, however, were mapped to the regions between 62.4 and 64.2 Mbp on BTA7 and 0 and 26.3 Mbp on BTA14 but because of the distance of the identified chromosomal regions to the locations of our studied genes, SLC27A6 and FABP 4 cannot be considered the candidate genes for the identified QTL. The absence of confidence intervals for the discovered QTL (Bouwman et al., 2011) makes it difficult to know how precise the QTL mapping was when comparing results from different studies. In another genome-wide screen for FA QTL using 1,536 SNP (Schennink et al., 2009b; Stoop et al., 2009), no QTL were found on BTA7 matching associations with milk FA concentrations for SLC27A6 discovered in our study. However, QTL for SFA, UFA, and myristic acid (14:0) concentrations, and SFA:UFA ratio in milk were found around $0 \mathrm{cM}$ on BTA14, but FABP 4 located on BTA14 at $42 \mathrm{cM}$ was too distant to be considered as a candidate gene for the QTL. Inconsistencies between 
results of the genome-wide and our candidate gene association studies might be explained by the lack of sufficient power of the relatively small numbers of SNP markers used in the genome-wide association studies to detect some associations determined in our study. Overall, the information about associations of genetic polymorphisms in SLC27A6 and FABP4 and milk FA composition can be used to produce milk with desirable FA profile using genetic selection. The future directions of research on genetic regulation of milk FA composition, however, should be focused on discovering new associations between different genetic polymorphisms and milk FA composition with subsequent validation of current and new discoveries in different populations of animals to find a group of genetic markers that can provide consistent results and, ideally, be associated with additive changes in a trait of interest.

\section{CONCLUSIONS}

The results of our study showed that genetic polymorphisms in SLC27A6 and FABP 4 were significantly associated with SFA, UFA, and MUFA concentrations, and SFA:UFA ratio in milk during the first 3 mo of lactation, leading to significant associations for some of the traits during the entire 305-d lactation period as well. Pairwise comparisons between intragenic haplotypes revealed that haplotypes $\mathrm{H} 3$ of $F A B P 4$ and $S L$ C27A6, respectively, were the most desirable to select for milk with a lower concentration of SFA and a higher concentration of UFA, and tag SNP for the corresponding haplotypes were identified to distinguish them from other haplotypes. Percentages of genetic variance explained by haplotype substitutions in each gene were relatively high, considering that complex traits such as milk FA are defined by many different genes. We found no significant associations between $F A B P 3$ and any of the studied traits because the main function of FABP3 is to transport FA for $\beta$-oxidation, not for TAG biosynthesis. To the best of our knowledge, this study is the first to test associations between SLC27A6, FABP3, and $F A B P 4$ polymorphisms and milk FA composition. The information about associations of $F A B P 4$ and SLC27A6 polymorphisms with milk FA composition can be used to select animals producing milk with a lower concentration of SFA and a higher concentration of UFA.

\section{ACKNOWLEDGMENTS}

We acknowledge the assistance of personnel at Iowa State University (Ames) and Kansas State University (Manhattan) dairy farms with collection of milk samples. We also appreciate the help with DNA sequencing and primer biosynthesis from the DNA Facility of the
Iowa State University Office of Biotechnology and with animal genotyping from Patrick S. Schnable's laboratory (Iowa State University). Funding for the study was provided by National Research Initiative Grant no. 2005-35205-16235 from the USDA/CSREES.

\section{REFERENCES}

Arnould, V. M., and H. Soyeurt. 2009. Genetic variability of milk fatty acids. J. Appl. Genet. 50:29-39.

Barendse, W., R. J. Bunch, M. B. Thomas, and B. E. Harrison. 2009. A splice site single nucleotide polymorphism of the fatty acid binding protein 4 gene appears to be associated with intramuscular fat deposition in longissimus muscle in Australian cattle. Anim. Genet. 40:770-773.

Bastin, C., N. Gengler, and H. Soyeurt. 2011. Phenotypic and genetic variability of production traits and milk fatty acid contents across days in milk for Walloon Holstein first-parity cows. J. Dairy Sci. 94:4152-4163.

Benjamini, Y., and Y. Hochberg. 1995. Controlling the false discovery rate: A practical and powerful approach to multiple testing. J. R. Stat. Soc., B 57:289-300.

Binas, B., B. Gusterson, R. Wallace, and A. J. Clark. 1995. Epithelial proliferation and differentiation in the mammary gland do not correlate with cFABP gene expression during early pregnancy. Dev. Genet. 17:167-175.

Binas, B., E. Spitzer, W. Zschiesche, B. Erdmann, A. Kurtz, T. Muller, C. Niemann, W. Blenau, and R. Grosse. 1992. Hormonal induction of functional differentiation and mammary-derived growth inhibitor expression in cultured mouse mammary gland explants. In Vitro Cell. Dev. Biol. 28A:625-634.

Bionaz, M., and J. J. Loor. 2008a. ACSL1, AGPAT6, FABP3, LPIN1, and SLC27A6 are the most abundant isoforms in bovine mammary tissue and their expression is affected by stage of lactation. J. Nutr. 138:1019-1024.

Bionaz, M., and J. J. Loor. 2008b. Gene networks driving bovine milk fat synthesis during the lactation cycle. BMC Genomics 9:366.

Bobe, G., E. G. Hammond, A. E. Freeman, G. L. Lindberg, and D. C. Beitz. 2003. Texture of butter from cows with different milk fatty acid compositions. J. Dairy Sci. 86:3122-3127.

Böhmer, F. D., R. Kraft, A. Otto, C. Wernstedt, U. Hellman, A. Kurtz, T. Muller, K. Rohde, G. Etzold, W. Lehmann, P. Langen, C.-H. Heldin, and R. Grosse. 1987. Identification of a polypeptide growth inhibitor from bovine mammary gland. Sequence homology to fatty acid- and retinoid-binding proteins. J. Biol. Chem. 262:15137-15143.

Bonen, A., A. Chabowski, J. J. Luiken, and J. F. Glatz. 2007. Is membrane transport of FFA mediated by lipid, protein, or both? Mechanisms and regulation of protein-mediated cellular fatty acid uptake: Molecular, biochemical, and physiological evidence. Physiology (Bethesda) 22:15-29.

Bouwman, A. C., H. Bovenhuis, M. H. Visker, and J. A. van Arendonk. 2011. Genome-wide association of milk fatty acids in Dutch dairy cattle. BMC Genet. 12:43. http://dx.doi.org/10.1186/14712156-12-43.

Cho, S., T. S. Park, D. H. Yoon, H. S. Cheong, S. Namgoong, B. L. Park, H. W. Lee, C. S. Han, E. M. Kim, I. C. Cheong, H. Kim, and H. D. Shin. 2008. Identification of genetic polymorphisms in FABP3 and FABP4 and putative association with back fat thickness in Korean native cattle. BMB Rep. 41:29-34.

Chouinard, P. Y., L. Corneau, A. Saebo, and D. E. Bauman. 1999. Milk yield and composition during abomasal infusion of conjugated linoleic acids in dairy cows. J. Dairy Sci. 82:2737-2745.

Christie, W. W. 1982. A simple procedure for rapid transmethylation of glycerolipids and cholesteryl esters. J. Lipid Res. 23:1072-1075.

Clark, A. J., C. Neil, B. Gusterson, J. McWhir, and B. Binas. 2000. Deletion of the gene encoding H-FABP/MDGI has no overt effects in the mammary gland. Transgenic Res. 9:439-444. 
Clarke, R., C. Frost, R. Collins, P. Appleby, and R. Peto. 1997. Dietary lipids and blood cholesterol: Quantitative meta-analysis of metabolic ward studies. BMJ 314:112-117.

Doege, H., and A. Stahl. 2006. Protein-mediated fatty acid uptake: Novel insights from in vivo models. Physiology (Bethesda) 21:259-268.

Doreau, M., and Y. Chilliard. 1997. Digestion and metabolism of dietary fat in farm animals. Br. J. Nutr. 78(Suppl. 1):S15-S35.

Furuhashi, M., and G. S. Hotamisligil. 2008. Fatty acid-binding proteins: Role in metabolic diseases and potential as drug targets. Nat. Rev. Drug Discov. 7:489-503.

Gabriel, S., L. Ziaugra, and D. Tabbaa. 2009. SNP genotyping using the Sequenom MassARRAY iPLEX platform. Unit 2.12 in Current Protocols in Human Genetics. 10.1002/0471142905.hg0212s60.

Gerbens, F., A. Jansen, A. J. van Erp, F. Harders, T. H. Meuwissen, G. Rettenberger, J. H. Veerkamp, and M. F. te Pas. 1998. The adipocyte fatty acid-binding protein locus: Characterization and association with intramuscular fat content in pigs. Mamm. Genome 9:1022-1026.

Gilmour, A. R. B. J. Gogel, B. R. Cullis, and R. Thompson. 2009 ASReml User Guide. Release 3.0. VSN International Ltd., Hemel Hempstead, UK.

Gimeno, R. E., A. M. Ortegon, S. Patel, S. Punreddy, P. Ge, Y. Sun, H. F. Lodish, and A. Stahl. 2003. Characterization of a heart-specific fatty acid transport protein. J. Biol. Chem. 278:16039-16044.

Gross, J., H. A. van Dorland, R. M. Bruckmaier, and F. J. Schwarz. 2011. Milk fatty acid profile related to energy balance in dairy cows. J. Dairy Res. 78:479-488.

Gutgesell, A., R. Ringseis, and K. Eder. 2009. Short communication: Dietary conjugated linoleic acid down-regulates fatty acid transporters in the mammary glands of lactating rats. J. Dairy Sci. 92:1169-1173

Hara, A., and N. S. Radin. 1978. Lipid extraction of tissues with a low-toxicity solvent. Anal. Biochem. 90:420-426.

Hoashi, S., T. Hinenoya, A. Tanaka, H. Ohsaki, S. Sasazaki, M. Taniguchi, K. Oyama, F. Mukai, and H. Mannen. 2008. Association between fatty acid compositions and genotypes of FABP4 and LXR-alpha in Japanese black cattle. BMC Genet. 9:84.

Hooper, L., C. D. Summerbell, R. Thompson, D. Sills, F. G. Roberts, H. Moore, and G. Davey Smith. 2011. Reduced or modified dietary fat for preventing cardiovascular disease. Cochrane Database Syst. Rev. 7 .

Horton, J. D., J. L. Goldstein, and M. S. Brown. 2002. SREBPs Activators of the complete program of cholesterol and fatty acid synthesis in the liver. J. Clin. Invest. 109:1125-1131.

Hotamisligil, G. S., R. S. Johnson, R. J. Distel, R. Ellis, V. E. Papaioannou, and B. M. Spiegelman. 1996. Uncoupling of obesity from insulin resistance through a targeted mutation in aP2, the adipocyte fatty acid binding protein. Science 274:1377-1379.

Hurtaud, C., F. Faucon, S. Couvreur, and J. L. Peyraud. 2010. Linear relationship between increasing amounts of extruded linseed in dairy cow diet and milk fatty acid composition and butter properties. J. Dairy Sci. 93:1429-1443.

Huth, P. J., and K. M. Park. 2012. Influence of dairy product and milk fat consumption on cardiovascular disease risk: A review of the evidence. Adv. Nutr. 3:266-285.

Huynh, H. T., C. Larsson, S. Narod, and M. Pollak. 1995. Tumor suppressor activity of the gene encoding mammary-derived growth inhibitor. Cancer Res. 55:2225-2231.

Kaylegian, K. E., and R. C. Lindsay. 1992. Performance of selected milk fat fractions in cold-spreadable butter. J. Dairy Sci. 75:3307-3317.

Krauss, R. M., R. H. Eckel, B. Howard, L. J. Appel, S. R. Daniels, R. J. Deckelbaum, J. W. Erdman Jr., P. Kris-Etherton, I. J. Goldberg, T. A. Kotchen, A. H. Lichtenstein, W. E. Mitch, R. Mullis, K. Robinson, J. Wylie-Rosett, S. St Jeor, J. Suttie, D. L. Tribble, and T. L. Bazzarre. 2000. AHA Dietary Guidelines: Revision 2000: A statement for healthcare professionals from the Nutrition Committee of the American Heart Association. Circulation 102:22842299.
Kris-Etherton, P. M., and S. Yu. 1997. Individual fatty acid effects on plasma lipids and lipoproteins: Human studies. Am. J. Clin. Nutr. 65(Suppl.):1628S-1644S.

Lande, R., and R. Thompson. 1990. Efficiency of marker-assisted selection in the improvement of quantitative traits. Genetics 124:743-756.

Larkin, M. A., G. Blackshields, N. P. Brown, R. Chenna, P. A. McGettigan, H. McWilliam, F. Valentin, I. M. Wallace, A. Wilm, R Lopez, J. D. Thompson, T. J. Gibson, and D. G. Higgins. 2007. Clustal W and Clustal X version 2.0. Bioinformatics 23:29472948

Littell, R. C., P. R. Henry, and C. B. Ammerman. 1998. Statistical analysis of repeated measures data using SAS procedures. J. Anim. Sci. 76:1216-1231

McNamara, J. P. 1989. Regulation of bovine adipose tissue metabolism during lactation. 5. Relationships of lipid synthesis and lipolysis with energy intake and utilization. J. Dairy Sci. 72:407-418.

Mele, M., G. Conte, B. Castiglioni, S. Chessa, N. P. Macciotta, A Serra, A. Buccioni, G. Pagnacco, and P. Secchiari. 2007. Stearoylcoenzyme A desaturase gene polymorphism and milk fatty acid composition in Italian Holsteins. J. Dairy Sci. 90:4458-4465.

Mele, M., R. Dal Zotto, M. Cassandro, G. Conte, A. Serra, A. Buccioni, G. Bittante, and P. Secchiari. 2009. Genetic parameters for conjugated linoleic acid, selected milk fatty acids, and milk fatty acid unsaturation of Italian Holstein-Friesian cows. J. Dairy Sci. 92:392-400.

Mensink, R. P., P. L. Zock, A. D. Kester, and M. B. Katan. 2003. Effects of dietary fatty acids and carbohydrates on the ratio of serum total to HDL cholesterol and on serum lipids and apolipoproteins: A meta-analysis of 60 controlled trials. Am. J. Clin. Nutr. $77: 1146-1155$

Morris, C. A., N. G. Cullen, B. C. Glass, D. L. Hyndman, T. R. Manley, S. M. Hickey, J. C. McEwan, W. S. Pitchford, C. D. Bottema and M. A. Lee. 2007. Fatty acid synthase effects on bovine adipose fat and milk fat. Mamm. Genome 18:64-74.

Mozaffarian, D., R. Micha, and S. Wallace. 2010. Effects on coronary heart disease of increasing polyunsaturated fat in place of saturated fat: A systematic review and meta-analysis of randomized controlled trials. PLoS Med. 7:e1000252.

Nafikov, R. A., J. P. Schoonmaker, K. T. Korn, K. Noack, D. J. Garrick, K. J. Koehler, J. Minick-Bormann, J. M. Reecy, D. E. Spurlock, and D. C. Beitz. 2013. Sterol regulatory element binding transcription factor 1 (SREBF1) polymorphism and milk fatty acid composition. J. Dairy Sci. 96:2605-2616. http://dx.doi. org/10.3168/jds.2012-6075

Noakes, M., P. J. Nestel, and P. M. Clifton. 1996. Modifying the fatty acid profile of dairy products through feedlot technology lowers plasma cholesterol of humans consuming the products. Am. J. Clin. Nutr. 63:42-46.

Pollard, K. S., H. N. Gilbert, Y. Ge, S. Taylor, and S. Dudoit. 2011 multtest: Resampling-based multiple hypothesis testing. $\mathrm{R}$ package version 2.14.0. R Foundation for Statistical Computing, Vienna, Austria.

Rozen, S., and H. Skaletsky. 2000. Primer3 on the WWW for general users and for biologist programmers. Methods Mol. Biol. $132: 365-386$.

Rudolph, M. C., J. L. McManaman, T. Phang, T. Russell, D. J. Kominsky, N. J. Serkova, T. Stein, S. M. Anderson, and M. C. Neville. 2007. Metabolic regulation in the lactating mammary gland: A lipid synthesizing machine. Physiol. Genomics 28:323-336.

Sawalha, R. M., J. F. Keown, S. D. Kachman, and L. D. Van Vleck. 2005. Evaluation of autoregressive covariance structures for testday records of Holstein cows: Estimates of parameters. J. Dairy Sci. 88:2632-2642

Schennink, A., H. Bovenhuis, K. M. Leon-Kloosterziel, J. A. van Arendonk, and M. H. Visker. 2009a. Effect of polymorphisms in the FASN, OLR1, PPARGC1A, PRL and STAT5A genes on bovine milk-fat composition. Anim. Genet. 40:909-916.

Schennink, A., J. M. Heck, H. Bovenhuis, M. H. Visker, H. J. van Valenberg, and J. A. van Arendonk. 2008. Milk fatty acid unsatu- 
ration: Genetic parameters and effects of stearoyl-CoA desaturase (SCD1) and acyl CoA:diacylglycerol acyltransferase 1 (DGAT1). J. Dairy Sci. 91:2135-2143.

Schennink, A., W. M. Stoop, M. H. Visker, J. M. Heck, H. Bovenhuis, J. J. van der Poel, H. J. van Valenberg, and J. A. van Arendonk. 2007. DGAT1 underlies large genetic variation in milk-fat composition of dairy cows. Anim. Genet. 38:467-473.

Schennink, A., W. M. Stoop, M. H. Visker, J. J. van der Poel, H. Bovenhuis, and J. A. van Arendonk. 2009b. Short communication: Genome-wide scan for bovine milk-fat composition. II. Quantitative trait loci for long-chain fatty acids. J. Dairy Sci. 92:46764682.

Siri-Tarino, P. W., Q. Sun, F. B. Hu, and R. M. Krauss. 2010. Metaanalysis of prospective cohort studies evaluating the association of saturated fat with cardiovascular disease. Am. J. Clin. Nutr. 91:535-546.

Skeaff, C. M., and J. Miller. 2009. Dietary fat and coronary heart disease: Summary of evidence from prospective cohort and randomised controlled trials. Ann. Nutr. Metab. 55:173-201.

Soyeurt, H., P. Dardenne, A. Gillon, C. Croquet, S. Vanderick, P Mayeres, C. Bertozzi, and N. Gengler. 2006. Variation in fatty acid contents of milk and milk fat within and across breeds. J. Dairy Sci. 89:4858-4865.

Specht, B., N. Bartetzko, C. Hohoff, H. Kuhl, R. Franke, T. Borchers, and F. Spener. 1996. Mammary derived growth inhibitor is not a distinct protein but a mix of heart-type and adipocyte-type fatty acid-binding protein. J. Biol. Chem. 271:19943-19949.

Stahl, A. 2004. A current review of fatty acid transport proteins (SLC27). Pflugers Arch. 447:722-727.
Stephens, M., and P. Donnelly. 2003. A comparison of Bayesian methods for haplotype reconstruction from population genotype data. Am. J. Hum. Genet. 73:1162-1169.

Stephens, M., N. J. Smith, and P. Donnelly. 2001. A new statistical method for haplotype reconstruction from population data. Am. J. Hum. Genet. 68:978-989.

Stoop, W. M., A. Schennink, M. H. Visker, E. Mullaart, J. A. van Arendonk, and H. Bovenhuis. 2009. Genome-wide scan for bovine milk-fat composition. I. Quantitative trait loci for short- and medium-chain fatty acids. J. Dairy Sci. 92:4664-4675.

Stoop, W. M., J. A. van Arendonk, J. M. Heck, H. J. van Valenberg, and H. Bovenhuis. 2008. Genetic parameters for major milk fatty acids and milk production traits of Dutch Holstein-Friesians. J. Dairy Sci. 91:385-394

Stranger, B. E., E. A. Stahl, and T. Raj. 2011. Progress and promise of genome-wide association studies for human complex trait genetics. Genetics 187:367-383.

Tuncman, G., E. Erbay, X. Hom, I. De Vivo, H. Campos, E. B. Rimm, and G. S. Hotamisligil. 2006. A genetic variant at the fatty acid-binding protein aP2 locus reduces the risk for hypertriglyceridemia, type 2 diabetes, and cardiovascular disease. Proc. Natl. Acad. Sci. USA 103:6970-6975.

Vogel Hertzel, A., and D. A. Bernlohr. 2000. The mammalian fatty acid-binding protein multigene family: Molecular and genetic insights into function. Trends Endocrinol. Metab. 11:175-180.

Wang, Q., T. Guan, H. Li, and D. A. Bernlohr. 2009. A novel polymorphism in the chicken adipocyte fatty acid-binding protein gene (FABP4) that alters ligand-binding and correlates with fatness. Comp. Biochem. Physiol. B Biochem. Mol. Biol. 154:298-302. 